\title{
Sediment capture in flood plains of the Mississippi River: A case study in Cat Island National Wildlife Refuge, Louisiana
}

\author{
MATTHEW SMITH ${ }^{1}$ \& SAMUEL J. BENTLEY, Sr. ${ }^{1,2}$ \\ 1 Department of Geology and Geophysics, Louisiana State University, Baton Rouge, Louisiana USA \\ 2 Coastal Studies Institute, Louisiana State University, Baton Rouge, Louisiana, USA \\ sjb@1su.edu
}

\begin{abstract}
To plan restoration of the Mississippi River Delta, it is imperative to know how much sediment the Mississippi River currently provides. Recent research has demonstrated that between Tarbert Landing and St Francisville on the Mississippi, as much as 67 million metric tons (Mt) per year is lost from river transport, of which $\sim 16 \mathrm{Mt}$ is muddy suspended sediment. So where does this sediment go? Two pathways for loss have been proposed: riverbed storage, and overbank deposition in regions that lack manmade levées. Cat Island National Wildlife Refuge, on the unleveed Mississippi River east bank near St Francisville, Louisiana, consists of undisturbed bottomland forest that is inundated most years by river flooding. To determine fluvial sediment accumulation rates (SAR) from flooding, pushcores 40-50 cm long were collected then dated by $\mathrm{Pb}-210$ and Cs-137 geochronology. Preliminary data suggests that muddy sediment accumulation is $10-13 \%$ of muddy suspended sediment lost from river transport along this river reach.
\end{abstract}

Key words Mississippi River; flood plain; sediment accumulation; Pb-210; Cs-137

\section{INTRODUCTION}

The Mississippi River (MR) has provided sediment to the coast of Louisiana for the last 7000 years. Throughout this time the river has shifted course, providing sediment along different localities of the Louisiana coast. Over these last 7000 years there has been a natural net gain of land. However, this has changed within the last century (Blum and Roberts, 2009). After the 1927 Great Flood the US Army Corps of Engineers was tasked with creating a system of levees, traps, and dams to help contain the Mississippi River to prevent another catastrophic flood from occurring. This has thus kept the Mississippi River flowing on its current course since 1927, and has also limited overbank flooding in the alluvial valley and delta. In the delta, this sediment limitation has been implicated as one primary contributor to catastrophic coastal deltaic land loss over the last 80 years (Barras et al., 2008; Blum and Roberts, 2009). Large river-sediment diversions have been proposed to help mitigate coastal Mississippi Delta land loss (LACPRA, 2012). However for this to be successful we must know how much sediment the Mississippi River can provide.

Allison et al. (2012) studied MR sediment delivery in water years 2008-2010, and demonstrated that during these years, the MR lost approximately $67 \mathrm{Mt}$ of sediment from transport between gauges at Tarbert Landing and St Francisville, just downstream from the branching of the Atchafalaya River distributary at the Old River Control Structure, and upstream from the city of Baton Rouge. Of this sediment loss, $\sim 16 \mathrm{Mt}$ was mud, and the rest sand. So where does this sediment go? Two pathways for loss have been proposed: riverbed storage, and overbank deposition in regions that lack manmade levees (Allison et al., 2012).

Along the reach of the MR between Tarbert Landing and St Francisville, approx. $276 \mathrm{~km}^{2}$ of flood plain are not separated from the MR by manmade levees, and so may flood naturally during seasonal high water (Fig. 1B). This area includes both regions that are bordered by uplands, as well as regions where extensive tracts of flood plain remain inside the main-line levee system (Fig. 1B). The objective of this study is to constrain sediment capture from the MR by natural floodplains, by measuring floodplain sediment accumulation rates in flood-plain cores. 

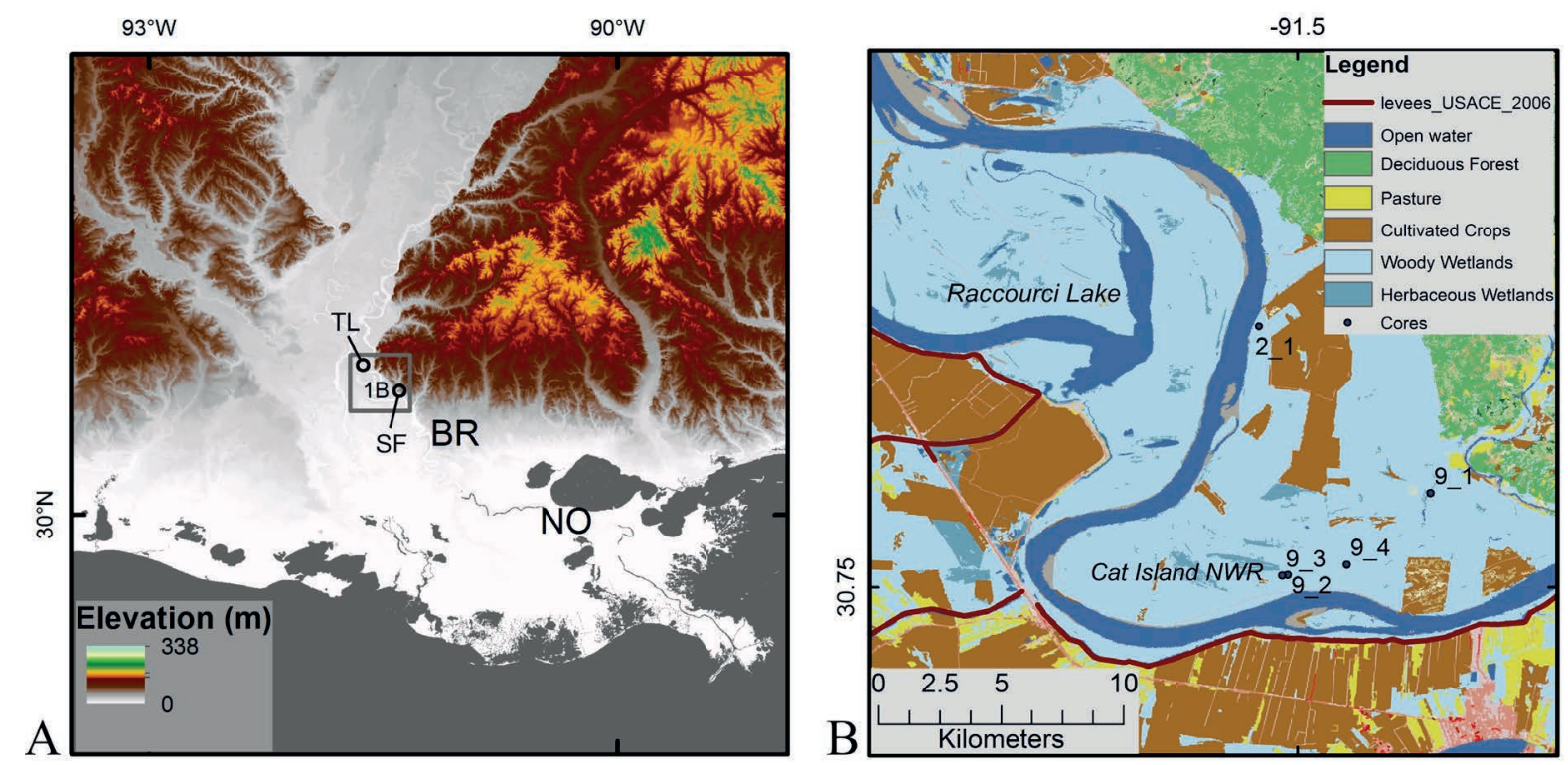

Fig. 1 (A) Colour-relief map of the lower Mississippi River valley and delta, showing inset of study area, and locations of river gauging locations at Tarbert Landing (TL) and St Francisville (SF) cited in Allison et al. (2012), and Baton Rouge (BR) and New Orleans (NO) for reference. (B) Inset land-use map of study area, showing location of Cat Island National Wildlife Refuge (NWR), core locations, and extent of main-line Mississippi River levees. The light blue regions (with enclosed brown/cultivated areas) delineate forested flood plains, not protected by levees, which are inundated by annual river floods, and where sediment delivered by the river is likely to accumulate. Elevation and land-use data from USGS (http://www.nationalmap.gov), and levee locations from the State of Louisiana (http://map.la.gov/losco_2007_Zip.html).

\section{METHODS}

In February and August 2013, five sediment cores were collected from the flood plain in and near Cat Island National Wildlife Refuge (NWR), on the unlevéed Mississippi east bank near St Francisville, which consists of undisturbed bottomland forest that is inundated most years by river flooding. Samples were collected using a gouge auger of $5.7 \mathrm{~cm}$ internal diameter (AMS Inc., American Falls Idaho, USA), to minimize core compaction during sampling. The auger was pushed $40-50 \mathrm{~cm}$ into flood-plain soil, rotated and recovered. Sediment was then placed into a longitudinally split plastic pipe, which was sealed for transport back to the laboratory.

Each core was photographed and then subsampled at $2 \mathrm{~cm}$ intervals for granulometric and radiochemical analysis. Grain size over the 0.5-3000 micron range was measured using a Beckman Coulter LS13-320 laser diffraction instrument (Beckman Coulter, Miami Florida USA), after samples were immersed overnight in an aqueous solution of $0.05 \%$ sodium phosphate and dispersed ultrasonically.

Samples for radionuclide measurements were dried, ground, and sealed in $50 \times 9 \mathrm{~mm}$ petri dishes, then counted for 24 hours on low-background planar gamma detectors (for ${ }^{210} \mathrm{~Pb}$, after waiting 15 days for ingrowth of supported ${ }^{210} \mathrm{~Pb}$ parent isotopes). Correction for self-absorption of ${ }^{210} \mathrm{~Pb}$ was done using the method of Cutshall et al. (1983). Total ${ }^{210} \mathrm{~Pb}$ was determined by measurement of the $46.5-\mathrm{KeV}{ }^{210} \mathrm{~Pb}$ gamma peak. Supported ${ }^{210} \mathrm{~Pb}$ from the decay of ${ }^{226} \mathrm{Ra}$ within sediment was determined by measurement of ${ }^{226} \mathrm{Ra}$ granddaughters ${ }^{214} \mathrm{~Pb}$ (at 295 and $352 \mathrm{KeV}$ ) and ${ }^{214} \mathrm{Bi}\left(\right.$ at $609 \mathrm{KeV}$ ). Excess (unsupported) ${ }^{210} \mathrm{~Pb}$ was determined by subtracting total ${ }^{210} \mathrm{~Pb}$ activity from supported ${ }^{210} \mathrm{~Pb}$ activity for each interval, and decay-corrected to the date of collection. Activities are reported in decays per minute (dpm), with one $\mathrm{dpm}=1 / 60$ Becquerels. Activity errors are derived from detector counting statistics. Minimum detectable activity for excess ${ }^{210} \mathrm{~Pb}$ is $0.1 \mathrm{dpm} \mathrm{g}^{-1}$, which is approximately three times the counting error for supported activity.

SARs were derived from ${ }^{210} \mathrm{~Pb}$ observations using a steady-state end-member solution to the advection-diffusion-reaction equation for radioactive decay and sedimentation only (Nittrouer and 
Sternberg, 1981). Assuming negligible bioturbation, and that only decay and sediment accumulation rates influence excess ${ }^{210} \mathrm{~Pb}$ activity, apparent SAR $\left(S, \mathrm{~cm}_{\text {year }}{ }^{-1}\right)$ can be calculated from a least-squares regression using equation (1), and depth and activity measurements of ${ }^{210} \mathrm{~Pb}$ :

$$
A_{\mathrm{z}}=A_{0} \exp (-\lambda z / S)
$$

where $A_{0}$ is excess ${ }^{210} \mathrm{~Pb}$ activity extrapolated to the sediment surface, $A_{\mathrm{z}}$ is activity at depth $z$, and $\lambda$ is the radioactive decay coefficient for ${ }^{210} \mathrm{~Pb}\left(0.031\right.$ year $\left.^{-1}\right)$. To relate sediment accumulation to fluvial supply, local sediment mass accumulation rates $\left(\mathrm{MAR}_{\mathrm{L}}, \mathrm{g} / \mathrm{cm}^{2}\right.$ year $\left.{ }^{-1}\right)$ were determined:

$$
\mathrm{MAR}=S^{*}(1-\phi) \rho_{\mathrm{S}}
$$

where $S^{*}$ is sediment accumulation rate (cm/year), $\phi$ is the average porosity of the core and $\rho_{\mathrm{S}}$ is the assumed grain density of the sediment of $2.65 \mathrm{~g} / \mathrm{cm}^{3}$ (e.g. Muhammad et al., 2008). SARs were also calculated from activities of ${ }^{137} \mathrm{Cs}$, which is an anthropogenic radioisotope, first introduced to the atmosphere in 1954 by nuclear bomb tests. Introduction to the atmosphere peaked in 19631964 and dropped to insignificant levels by 1980 (e.g. Anderson et al., 1988). Activities of ${ }^{137} \mathrm{Cs}$ were determined directly by counting the ${ }^{137} \mathrm{Cs} 661-\mathrm{keV}$ peak. SARs then were calculated, assuming negligible bioturbation, from:

$$
S=\left(z_{\max }\right) /(T-1954)
$$

with maximum penetration depth $z_{\max }(\mathrm{cm})$ of ${ }^{137} \mathrm{Cs}$, and the year of sample collection $T$ (Nittrouer et al., 1983).

Regional mass accumulation $\left(\mathrm{MAR}_{\mathrm{R}}\right)$ was estimated as the product of averaged local mass accumulation rates and area of flood plain not protected by levees. Flood-plain area was determined by creation and area-measurement of polygons in Google Earth Pro $^{\mathrm{TM}}$ for which polygon boundaries followed manmade levees, the river channel, or the boundary between flood plain (light blue in Fig. 1B) and upland forest (green in Fig. 1B). The potential for flooding in this region was further confirmed by study of inundation extent shown in Google Earth ${ }^{\mathrm{TM}}$ imagery during past high-water seasons, such as May 2011, and earlier.

\section{RESULTS}

\section{Grain size}

Core 2_1 was found to be composed of mostly sand with smaller quantities of silt in gradational beds. Cores 9_1,9_2,9_3, and 9_4 were primarily gradational to sharply bedded and mottled muddy sediment, with subtle gradations in grain size throughout.

\section{Radiochemistry and geochronology}

Core 2_1, collected from the natural levee of the river north of the Cat Island NWR, contains trace amounts of ${ }^{137} \mathrm{Cs}$ to a depth of $46 \mathrm{~cm}$, suggesting that at least the upper $\sim 46 \mathrm{~cm}$ have been deposited since 1954 . Activity of ${ }^{210} \mathrm{~Pb}$ shows no obvious decline with depth, suggesting that the entire core was deposited a during time period less than the half-life of ${ }^{210} \mathrm{~Pb}$, or $<22$ years. These observations allow calculation of minimum SAR for this core using ${ }^{137} \mathrm{Cs}$ of $\geq 0.75 \mathrm{~cm} /$ year, and for ${ }^{210} \mathrm{~Pb}, \geq 2.2 \mathrm{~cm} /$ year.

Table 1 Sediment SAR and MAR estimated from radiochemical measurements using methods described above. Porosity for MAR calculations was assumed to be 0.6 .

\begin{tabular}{llll}
\hline Core Number & $\begin{array}{l}{ }^{137} \mathrm{Cs} \text { SAR } \\
(\mathrm{cm} \text { year }\end{array}$ & $\begin{array}{l}\left.{ }^{-1}\right) \\
\left(\mathrm{cm} \mathrm{year}^{-1}\right)\end{array}$ & $\begin{array}{l}\text { Average MAR } \\
\left(\mathrm{g} \mathrm{cm}^{-2} \text { year }^{-1}\right)\end{array}$ \\
\hline $2 \_1$ & $\geq 0.75$ & $\geq 2.2$ & Not determined \\
$9 \_1$ & $0.18-0.22$ & 0.41 & 0.31 \\
$9 \_2$ & $>0.59$ & 1.5 & 1.11 \\
$9 \_3$ & $>0.59$ & 0.56 & 0.61 \\
$9 \_4$ & 0.50 & 0.28 & 0.41 \\
Averages excl. 2_1: & Min. values $=0.47$ & 0.69 & $0.49-0.73$ \\
\hline
\end{tabular}



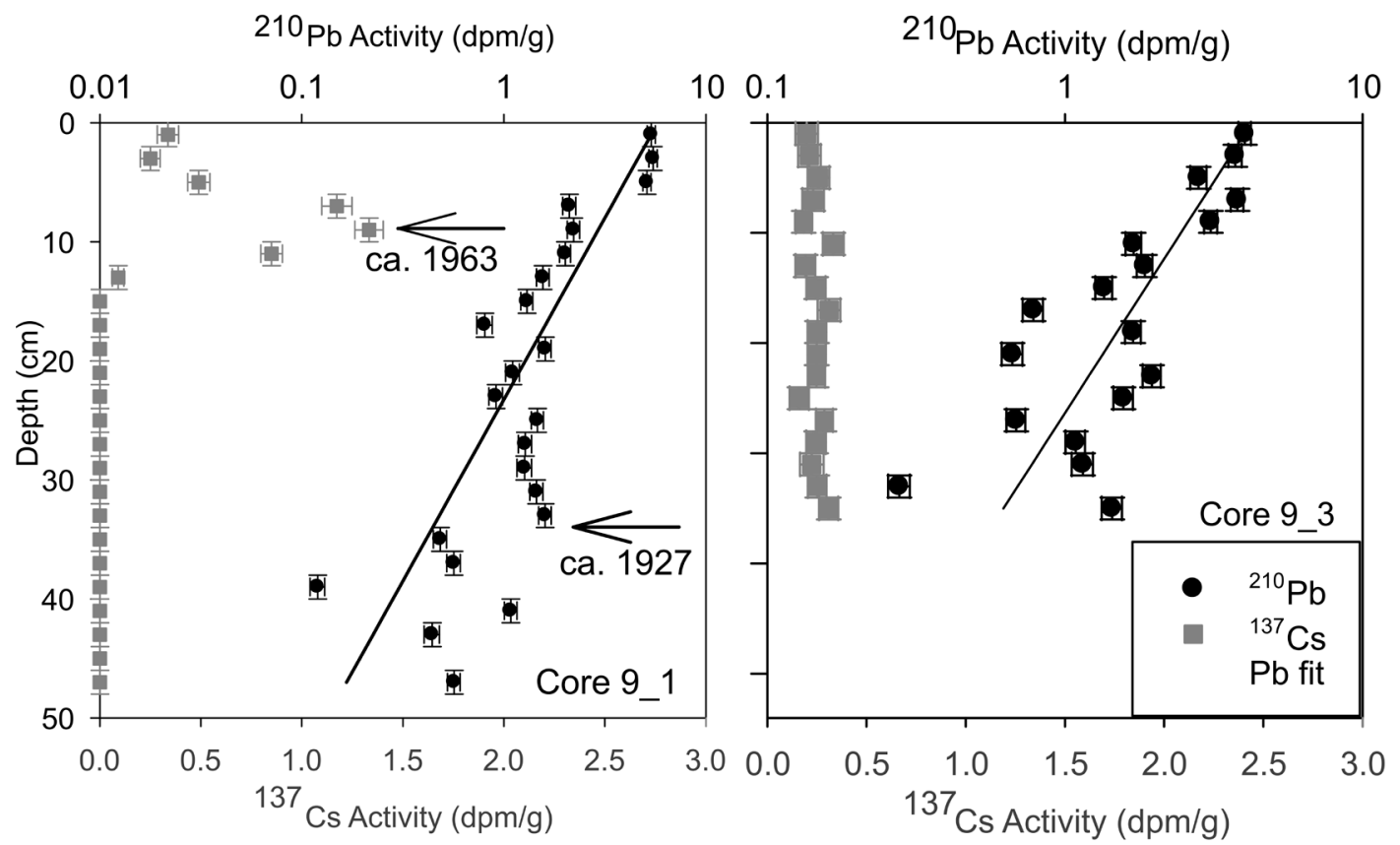

Fig. 2 Results of radiochemical analyses for cores 91 (left) and 93 (right), which are characteristic of the muddy cores collected for this study. The legend for core 933 applies to both figures. In core 9_1, the approximate depth of the 1963 time horizon is indicated by the arrow marking the ${ }^{137} \mathrm{Cs}$ subsurface maximum, and the approximate base of the 1927 flood layer is indicated by the lower arrow. Both plots show regressions for ${ }^{210} \mathrm{~Pb}$ data with the exponential sediment accumulation model presented in Methods.

Muddy cores collected from the floodplain all show declining activity of ${ }^{210} \mathrm{~Pb}$ with depth (Fig. 2), allowing regression estimates of ${ }^{210} \mathrm{~Pb} \mathrm{SAR}$ (Table 1). Two cores show clear subsurface maxima in ${ }^{137} \mathrm{Cs}$ (cores 9_1 and 9_4) (Fig. 2) allowing estimation of SAR based on the $1963{ }^{137} \mathrm{Cs}$ maximum (Table 1). Cores 9_2 and 9_3 display no ${ }^{137} \mathrm{Cs}$ subsurface maximum and ${ }^{137} \mathrm{Cs}$ penetrates to the core base (Fig. 2); these conditions allow only estimation of a minimum SAR based on the first deposition of ${ }^{137} \mathrm{Cs}$ in 1953 (Table 1).

\section{DISCUSSION AND CONCLUSIONS}

Highest minimum SAR for all cores were identified for core 2_1, collected from the natural levee within $200 \mathrm{~m}$ of the Mississippi River. Composed dominantly of sand, grain size is substantially coarser than other flood-plain cores, consistent with its location near the river, where coarsest sediment is likely to deposit. SAR estimates for this core are poorly constrained, and would be applicable only to a narrow corridor along the river levee.

Muddy flood-plain cores 911 to 94 yield an average SAR range of $0.47-0.69 \mathrm{~cm} \mathrm{year}^{-1}$, or $\mathrm{MAR}_{\mathrm{L}}$ of $0.49-0.73 \mathrm{~g} \mathrm{~cm}^{-2}$ year ${ }^{-1}$, using averages of the minimum estimates from ${ }^{137} \mathrm{Cs}$ data, and the average of ${ }^{210} \mathrm{~Pb}$ results for all four cores (Table 1). Considering the modest spatial coverage of our core data, and the wide range of SAR and MAR results, we suggest that, rather than attempting to spatially weight MAR results, this range represents a plausible range of typical values and uncertainty for sediment accumulation in the entire area subjected to flooding. Also, for the purposes of this pilot study, levee accumulation of sand will not be considered due to great uncertainty in the area encompassed by levee sedimentation, and uncertainty in MAR estimates.

Figure 1B displays two large areas of flood-plain/lowland forest that are subject to annual flooding (Cat Island, and Raccourci Lake) that together encompass $276 \mathrm{~km}^{2}$ that are subject to annual flooding, based on our GIS analysis (Fig. 1B). Both of these regions fall between the river gauging stations at Tarbert Landing and St. Francisville, according to Allison et al. (2012), between which stations $\sim 16 \mathrm{Mt}^{\text {year }}{ }^{-1}$ of muddy suspended sediment are lost from river transport. Downstream of St Francisville to Baton Rouge (Fig. 1A), we estimate an additional 
$94 \mathrm{~km}^{2}$ of lowland forest and agricultural land are subject to flooding and sediment accumulation. Using these areas and the $\mathrm{MAR}_{\mathrm{L}}$ estimates above, total regional sediment flood-sediment accumulation for Cat Island and Raccourci Lake flood plains is likely to be on the order of 1.642.11 Mt year ${ }^{-1}$, with an additional $0.56-0.72 \mathrm{Mt}^{\text {year }}{ }^{-1}$ deposited in flood plains downstream to Baton Rouge. Focusing on the Cat Island and Raccourci Lake regions, which lie along the Tarbert Landing-St Francisville reach analysed by Allison et al. (2012), flood-plain sediment accumulation is equivalent to $10-13 \%$ of the suspended sediment lost from transport along this reach annually, with an additional $2.5-4.5 \%$ deposited annually in flood plains downstream to Baton Rouge.

These results suggest that considerable sediment is accumulating in unleveed flood plains, but not enough to account for the suspended sediment deficit identified by Allison et al. (2012). Therefore, additional sediment sinks, including riverbed aggradation, should be studied to complete the sediment budget.

Acknowledgements Funding for this work was provided by the Louisiana State University College of Science, the Honors College, and the Billy and Ann Harrison Endowment for Sedimentary Geology, with the LSU Foundation. Field work was completed with permission from the United States Fish and Wildlife Service. The authors also thank Drs Kehui Xu and Tiffany Roberts for constructive reviews of this paper.

\section{REFERENCES}

Aalto, R. and Nittrouer, C. (2012) ${ }^{210} \mathrm{~Pb}$ geochronology of flood events in large tropical river systems. Phil. Trans. R. Soc. A 370, 2040-2074. doi: 10.1098/rsta.2011.0607

Allison, M.A., et al. (2012) A water and sediment budget for the lower Mississippi-Atchafalaya River in flood years 20082010: Implications for sediment discharge to the oceans and coastal restoration in Louisiana. Journal of Hydrology, 432 84-97.

Anderson, R.F., et al. (1988) Mixing of particles and organic constituents in sediments from the continental shelf and slope off Cape Cod: SEEP I Results. Continental Shelf Research, 8, 925-946.

Barras, J.A., Bernier, J.C., and Morton, R.A. (2008) Land area change in coastal Louisiana-A multidecadal perspective (from 1956 to 2006). U.S. Geological Survey Scientific Investigations Map 3019, scale 1:250,000, 14 p. pamphlet, accessed August 23, 2010 at, 61(1-2): 127-142. http://pubs.usgs.gov/sim/3019.

Blum, M.D., and Roberts, H.H (2009) Drowning of the Mississippi Delta Due to Insufficient Sediment Supply and Global Sealevel Rise. Nature Geoscience 2, 488-491.

Cutshall, N.H., Larsen, I.L. and Olsen, C.R. (1983) Direct analysis of ${ }^{210} \mathrm{~Pb}$ in sediment samples: self absorption corrections. Nuclear Instruments and Methods 206, 1-20.

LACPRA (Louisiana Coastal Protection and Restoration Authority) (2012) Louisiana's Coastal Master Plan. http://www.coastalmasterplan.louisiana.gov/. Accessed 01/10/2014.

Nittrouer, C.A., and Sternberg, R.W. (1981) The formation of sedimentary strata in an allochthonous shelf environment: the Washington continental shelf. Marine Geology 42, 201-232.

Nittrouer, C.A., et al. (1983) The effect of sediment mixing on ${ }^{210} \mathrm{~Pb}$ accumulation rates for the Washington continental shelf. Marine Geology 54, 201-221. 